\title{
Adoption of International Financial Reporting Standards (IFRS) and Assets Quality in the Nigerian Banking Sector: The Fundamental Effect Approach
}

\author{
Anthony Nzeribe Nwaubani \\ Department of Banking \& Finance, Michael Okpara Univ. of Agriculture, Umudike Nigeria \\ Department of Banking \& Finance, Nnamdi Azikiwe University, Awka Nigeria
}

Tel: 234-803-348-4357. E-mail: toninwaubani@yahoo.com

\author{
Cyprian Okey Okoro \\ Chukwuemeka Odumegwu Ojukwu University, Igbariam Nigeria
}

Tel: 234-804-430-3795.E-mail: cy.okoro2@yahoo.com

Received: December 11, 2018 Accepted: December 23, 2018 Published: December 23, 2018

doi:10.5296/jpmr.v4i2.14098

URL: https://doi.org/10.5296/jpmr.v4i2.14098

\begin{abstract}
The main purpose of this work is to examine the effect of the adoption of international financial reporting standards (IFRS) on assets quality in the Nigerian banking sector. Specifically the study sought to determine the effect of the adoption on asset quality, loan volume, net interest income and profit after tax of deposit money banks listed on the Nigerian Stock Exchange. The adopted research design is causal-comparative. Secondary data on ten out of sixteen listed deposit money banks on the Nigerian Stock Exchange by June 2018 were used. The banks which were selected via judgmental sampling technique were those whose annual financial statements for the immediate year before IFRS adoption year were available and contained figures under Nigerian GAAP/SAS and IFRS-equivalent. The data which were analyzed using paired student t-test approach were sourced from 2011 and 2012 annual reports of the selected banks except Zenith bank for which only 2011 annual financial reports were used. The variables of interest were grouped under Nigerian GAAP (SAS) and IFRS. Findings revealed that overall, the IFRS adoption indicates negative insignificant effect on assets quality of deposit money banks in Nigeria. The study therefore, recommends inter-alia that Financial Reporting Council of Nigeria should partner with the CBN to provide clarity on areas of regulatory hindrance to full and effective implementation of the IFRS with regular.
\end{abstract}


Keywords: International Financial Reporting Standards (IFRS), Assets Quality, IFRS Adoption, Nigerian GAAP

\section{Introduction}

The need for risk management in banks stems from the core nature of the banking business which revolves more around lending. Poor assets quality and low liquidity have been seen as the two key challenges of banks (Oino, 2015). Deteriorating assets quality in the banking sector has been of global concern particularly after the 2007-2009 global financial crisis. In Sub Saharan Africa including Nigeria, non-performing loans have been on the rise (EIB, 2016). In the view of Nwaubani and Ezeudu (2015) the banking system still remains the engine of growth in any economy in view of its crucial functions in the economy. Therefore the need for a sound banking system in any economy is obvious.

The directive for banks to adopt International Financial Reporting Standards (IFRS) in their financial reporting has been of interest to various local and international stakeholders. The primary objective of accounting is to provide useful financial information to stakeholders such as current investors, potential investors and lenders/creditors (Garcia, 2015). According to the author, the quality of information provided in financial reports determines the usefulness and reliability of such reports to users. According to IFRS Foundation (2017) accounting standards are a set of principles and rules companies follow when they prepare and publish their financial statements. The principles provide uniform and consistent yardstick for assessing and comparing performances of the organizations. They are the authoritative statements of best accounting practices and are issued by recognized expert accountancy bodies providing a guide on how accounting information should be recorded, reported and interpreted (Shil, Das \& Pramanik, 2009; Jamal, Shamsher, Taufiq \& Zulkarnain, 2011). National standards differ from country to country because the standards reflect unique economic and socio-political realities of each nation and these realities normally differ among nations. The differences in national standards introduce difficulties to investors and multinational corporations that need to prepare varying sets of financial statements for the different countries where their subsidiaries operate (Mande, 2014). With fast pace of globalization and integration of national financial markets the need for a common financial language becomes imperative (Herbert et al., 2013).

Besides the imperatives of globalization, in recent years several financial and accounting scandals have risen and the incidents of corporate frauds in the form of false financial reporting, irregular transactions and assets embezzlement have been on the rise globally (Ugbede, Mohd, \& Ahmad, 2014). These incidents have negatively affected the confidence and trust of the public and especially investors in financial reporting. To narrow the differences in national standards and to boost confidence and trust of local and international stakeholders in financial reporting; the International Accounting Standards Committee (IASC) later known as International Accounting Standards Board (IASB) commenced issuing International Accounting Standards (IAS). The IAS later became known as IFRS International Financial Reporting Standards (Mustafa, 2014). National accounting standards setting bodies of different countries are expected to adopt the IFRS. Adoption of IFRS by a country refers to an attempt to replace a country's standards with international financial 
reporting standards (IFRS). There is clear appreciation among stakeholders of the need for each country to adopt the IFRS.

In Nigeria, the issue of poor financial reporting was further exposed by the 2007-2009 global financial crisis which engulfed the nation's banking system in 2009. Many Nigerian banks had to be rescued and the stock market lost about $70 \%$ of its value (Sanusi, 2010). Questionable financial reporting practices such as poor disclosure and inaccurate reports by banks in Nigeria was fingered as one of the major fundamental contributing factors to the crisis in Nigeria (Sanusi 2010; Abata 2015). As part of the strategies to address these challenges and to integrate the Nigerian banking system into the global best practices in financial reporting, the economic entities were directed to mandatorily adopt the IFRS as a replacement for the locally issued Statement of Accounting Standards -SAS (Sanusi 2012). Consequently, the banks have transited to IFRS with effect from 2012 ((Herbert, Tsegba, Ohanele \& Anyahara 2013).

\subsection{Statement of the Problem}

A number of empirical studies have been carried out on the effect of IFRS adoption on the banking industry in Nigeria (Tanko 2012; Saidu \& Dauda, 2014; Yahaya, Yusuf, \& Dania, 2015; Elosiuba \& Okoye 2018). The problem is that most of the empirical studies are based on selective IFRS adoption by a few banks before the 2012 official adoption date in Nigeria. In this study, the effect of the IFRS adoption on banks' performances in Nigeria would be based on the mandatory adoption. Again, to the best of the knowledge of the researchers, there are very scanty empirical works (Eneje, Obidike, \& Chukwujekwu, 2016; Ajekwe, Ibiamke, \& Silas, 2017; Abba, Alabede, Okwa \& Soje, 2018) focusing on the effect of the adoption on assets quality of the Nigerian banks.

Equally most of the empirical studies on the effect of the mandatory/2012 adoption on banks' performance in Nigeria made use of data categorized as pre and post adoption data in their analysis. By this, the authors generated data for a number of years to 2011 and also a number of years from 2012. They did not employ IFRS-equivalent of the SAS/2011 accounting figures. In this study the analysis would be based on the SAS figures as at 2011 and the IFRS-equivalent of the SAS/2011 accounting figures in 2012.

Finally, another problem this study is poised to solve is the conflict in findings of the empirical studies on the effect of the IFRS adoption on general performance of banks in Nigeria. While Okpala (2012), Yahaya et al (2015), Akinleye (2016), Eriki, Modebe, Okoye and Erin (2017), Omaliko, Uzodimma and Okpala (2017), Abba, Alabede, Okwa and Soje (2018) document mainly significant positive effect, Abdul-Baki, et al (2014) indicates no impact with Tanko (2014), Eneje, Obidike and Chukwujekwu (2016), Elosiuban and Okoye (2018) reporting negative effect.

\section{Literature Review}

\subsection{Conceptual Framework}

2.1.1 Accounting standards: Meaning and relevance in financial reporting 
Accounting standards are those principles, opinions, interpretations, rules and regulations which guide organizations in preparing their financial reports (Akabom-Itam, 2013). They can also be seen as an information system through which financial and monetized information is generated for economic, social and political decisions (Yahaya \& Adenola, 2011). Business entities communicate their financial performance to the various stakeholders by way of financial statements. The relevance of accounting standards in financial reporting lies in the guidelines which they offer on how accounting information should be recorded, reported in the financial statements and interpreted in such as to make the information useful and relevant to the users. However, accounting standards differ across nations because of the national peculiarities. A commonly held view is that such differences reduce the quality and the relevance of accounting information (Ding, Hope, Jeanjean, \& Stolowy, 2007).

\subsubsection{National and International Accounting Standards}

There are national and international accounting standards. National accounting standards are set by the accounting standards setters/boards of each country. Accounting standards of a nation take into account the peculiarities of the country at the point in time thus are to a large extent peculiar to each country. On the other hand, according to Institute of Chartered Accountants in England and Wales (ICAEW, 2016), international accounting standards are accounting standards issued by the International Accounting Standards Board (IASB) and its predecessor, the International Accounting Standards Committee (IASC). The standards are international financial reporting standard (IFRSs) and international accounting standards (IASs).

IFRS are standards issued by IASB under the supervision of IFRS Foundation after 2001 when IASC was reconstituted into IASB while IAS are standards issued by IASC from 1973 to 2001. The IFRS and the IAS mainly constitute the international accounting standards and they are designed to apply to the general purpose financial statements of all profit-oriented entities including government business enterprises (GBEs) which as defined by the IPSASB are profit-oriented entities (Deloitte, 2015). However, it should be mentioned that The International Public Sector Accounting Standards Board (IPSASB) (formerly the Public Sector Committee of the International Federation of Accountants) generally develops international public sector accounting standards - IPSASs which focus on the accounting, auditing, and financial reporting needs of national, regional, and local governments, related governmental agencies, and the constituencies they serve. According to Oduware (2012), there are IPSASs cash basis and IPSASs accrual basis. The IPSASs accrual address public sector financial reporting issues that have not been comprehensively dealt with in existing International Financial Reporting Standards (IFRSs) or for which there is no related IFRS (Deloitte, 2015).

\subsubsection{Institutional Framework for Formulating Accounting Standards in Nigeria-Before IFRS}

Prior to the official adoption of IFRS in Nigeria on January 1, 2012, the Nigerian Generally Accepted Accounting Principles (NGAAP) were as capsulated in the Statement of Accounting standards (SASs). The SASs which were issued by Nigerian Accounting Standards Board (NASB) represented Nigerian national accounting standards. NASB which 
came into being in 1982 was the only recognized independent body in Nigeria responsible for the development and issuance of statement of Accounting Standards covering all sectors of the economy and regulatory agencies of government (Edogbanya \& Karmadin, 2014).

\subsubsection{The Emergence of IFRS - A Historical Perspective}

The need to have a unified set of accounting standards had long been identified by professionals and stakeholders all over the world. However, the arrival globalization has placed the need on the front burner, dominating international discussions and international fora among stake holders (Herbert et al., 2013; Ocansey \& Enahoro, 2014). Adopting a set of acceptable and unified accounting standards such as the IFRS provides investors and other users of the financial statements with the ability to make a sound comparison of financial performance of publicly listed firms across the globe. There is appears to be a strong global appreciation of this fact among stakeholders. The purpose of establishing IFRS is to meet this need (Trabelsi \& Trabelsi, 2014).

The concept of convergence of national accounting standards first arose in the late 1950s in response to post World War II economic integration and related increase in cross-border capital flow. Initial efforts focused on harmonization which term refers to efforts towards reducing differences among the accounting principles used in major capital markets round the globe. The notion of harmonization was by the 1990s replaced by the concept of convergence which refers to the development of a unified set of high-quality, international accounting standards which would be used in at least all major capital markets round the world. In 1973, the first international standards-setting body, International Accounting Standards Committee (IASC) was established to pursue the goal of unified set of standards. The standards issued by IASC are known as International Accounting Standards (IAS). However, IASs were not recognized by all stock exchanges throughout the world (ICAEW, 2016, p. 2). In the same 2000, the International Organization of Securities Commissions (IOSCO) endorsed IAS for use in connection with cross-border listings. In April 2001 the IASC was reconstituted into the International Accounting Standards Board (IASB) which agreed to adopt all IASs, and name future standards as international financial reporting standards- IFRSs (ICAEW, 2018).

Countries across the globe are persuaded to adopt the IFRSs as their private sector financial reporting standards based on the perceived benefits of IFRS. Adoption of IFRS can be voluntary or mandatory. It is mandatory when it is done in compliance with government directive. The process of adoption received a significant boost when in 2002 the European Union (EU) adopted a regulation requiring public companies to convert to IFRSs beginning in 2005 (Owolabi \& Iyoha, 2012). According to Deloitte, Touche Tohmatsu Ltd- Deloitte (2015), International Federation of Accountants - IFAC in October 2015 urged the G20 to call for global adoption of IFRSs. By 2017 there were tentatively about 166 jurisdictions that had achieved varying levels of IFRS adoption across the globe (IFRS Foundation, 2017b).

\subsubsection{IAS 39 and IFRS 9 Requirements: The Journey So Far}

The International Accounting Standards (IAS) 39 which was first issued in 1998 passed through various amendments until April 2009 when it was amended for annual improvements to IFRS (Deloitte, 2017). International financial reporting standards 9 was later issued in 
November 2009 to replace classification and measurement of financial assets requirements of IAS 39. The IFRS9 issued in November, 2009 was later reissued in October 2010 to capture new requirements with effective implementation date of January 2013. The replacement of remaining requirements of the IAS 39 was to be achieved in phases with each phase added to the standard as it was completed. The final version of IFRS 9 was issued in 2014 but to be mandatorily implemented effective 1 Jan 2018 (subject to local endorsement requirements). It supersedes all previous versions/phases of the IFRS 9. It may be noted that IAS $39-$ Financial Instruments: Recognition and Measurement specifies requirements for recognition and measurement of financial assets (including loans), financial liabilities and contracts to buy or sell non-financial items by financial entities inclusive of deposit money banks.

The current impairment/loan loss provisioning requirements under IAS 39 are based on an 'incurred loss model' which means that, credit losses are not recognized until a credit loss event occurs (Ernest \& Young, 2014). In the opinion of the authors, the incurred loss model in IAS 39 was fingered as a contributing factor to the delay in recognizing the credit losses which sparked the global financial crisis. The delayed recognition was recognized as a weak point in IAS39. Global concern was raised over the incurred loss approach with the G20 asking world accounting standard setting bodies to develop a single set of high-quality global standards. Consequently the International Accounting Standards Board resolved to fast track its project to replace IAS 39 (PricewaterhouseCoopers-PWC, 2014). The IFRS 9 was therefore issued as a response to the global concern over the incurred loss model.

The impairment requirements in final version of the IFRS 9 are driven by a forward-looking "expected credit loss" (ECL) model. The forward-looking information aspect entails that application of the standard will require considerable management discretion over how the ECLs will be affected by information on expected changes in macroeconomic conditions (PWC, 2014). The model has three stages- assets with12-month expected credit loss (ECL), assets with lifetime ECL without objective evidence of impairment and assets with lifetime ECL which have objective evidence of impairment at the reporting date.

\subsubsection{IAS 39 and IFRS 9 Requirements and Implications on Assets Quality}

The implications of the IFRS on asset quality could be linked to whether one is comparing Nigerian GAAP/CBN Prudential Guidelines to IAS or IFRS 9 as at January 2012 - the date of the official adoption. Before this date, the deposit money banks in Nigeria were preparing their annual reports according to the requirements of Nigerian GAAP/SAS and matters involving assets impairment/credit risk were addressed as prescribed by SAS10/CBN Prudential Guidelines (PWC, 2011). From the insight given by Deloitte (2017) the IFRS9 issued in November, 2009 was later reissued in October 2010 to capture new requirements with effective implementation date of January 2013. This fact implies that throughout 2011 IFRS 9 was not in force as its effective implementation date was January 2013. The 2013 date was again moved to 2015 which in 2014 was further shifted to 2018 when the final and complete version of the IFRS 9 was published to replace the IAS 39.

From the foregoing, in 2011, the applicable international standard/IFRS was IAS39. Therefore, in Nigeria, the comparison is between SAS1/CBN Prudential Guideline and IAS 
39. Assets impairment considerations are based on "incurred loss' model under IAS 39 while SAS 10 prescribes "perceived loss" approach. The incurred loss approach leads to delay in recognizing and treating of credit impairment and thus suggests a false sense of good quality assets. The SAS10/CBN prudential guidelines on the other hand were more prudential as they incorporated and treated informed-anticipated impairments.

\subsection{Review of Empirical Literature}

Umorem and Enang (2015) evaluated the effect of IFRS adoption on financial reporting quality among listed commercial banks in Nigeria through value-relevance tests using a relative and incremental research design. The study employed a sample of 48 year observations of twelve listed banks in Nigeria. Secondary data covering the period 2010 to 2013 were used with multiple regression (anchored on Ohlson model) for analysis. The overall results indicated that the earning per share, book value of equity and share prices of commercial banks have significantly improved following IFRS adoption. Suggestively, earnings per share and book value of equity are relevant in determining the value of shares in Nigerian commercial banks in the post IFRS era. This result is consistent with the findings in Trabelis and Trabelis (2014) - United Arab Emirate. IFRS emphasizes adequate disclosure in order to improve the value relevance of the financial statement.

Abata (2015) evaluated the impact of IFRS adoption on financial reporting practice in the Nigerian banking sector. The study employed comparative index approach in his analysis and thereafter used t-test for testing for significant difference. The sample consisted of 14 listed banks and secondary data were used. The outcomes confirm that IFRS adoption has positively and significantly impacted on financial reporting in the Nigerian banking industry. Yahaya, Yusuf and Dania (2015) examined the effect of the adoption of the International Financial Reporting Standards on the financial statements of Listed Deposit Money Banks in Nigeria. Ex-post facto design was employed -comparing the period 2004 to 2008 and 2009 to 2013. The study made use of logistic regression with dummy variable as the dependent variable while the independent variable were: profitability growth, leverage, liquidity, size, investment and age. The result indicated that IFRS adoption has positively impacted the overall financial performance and position of banks in Nigeria. Under IFRS, important financial performance figures, such as profitability and growth, appear to be higher. Eneje, Obidike and Chukwujekwu (2016) examined the effect of IFRS adoption on the mechanics of loan loss provisioning for Nigerian Banks. It analysed how the change in the recognition and measurement of loan loss provision affects the accounting quality of the banks. Thereby reducing the income smoothing behavior of the money deposit banks. Secondary data obtained from the deposit money banks' annual reports covering the 2005 to 2015 were used. Descriptive statistics and the ordinary least square multiple regression approach was used to analyze the data It was found that the limitation to recognize only incurred losses under IAS 39 significantly reduces income smoothing thereby improving earnings quality but delays recognition of future expected losses thus reducing asset quality. Akinleye (2016) employed ratio analysis to investigate the nexus between IFRS adoption and performance of money deposit banks in the Nigeria. Ten listed banks were randomly selected for analysis over the period 2009 to 2014. Secondary data (return on assets and equity) from annual reports of the 
banks were employed and analyzed using panel data pooled OLS approach. The results revealed that adoption of IFRS exert positive insignificant impact on performance of money deposit banks. This outcome contradicts the findings of significant impact reported in Yahaya, Yusuf and Dania (2015). Omaliko, Uzodimma and Okpala (2017) investigated the impact of IFRS on performance of listed deposit money banks in Nigeria using secondary data from annual reports of five banks for the period 2009 to 2016. The data were analyzed employing Wilcoxon model and the results indicated that IFRS adoption has significant positive impact on profitability of the deposit money banks in Nigeria. Eriki, Modebe, Okoye, and Erin (2017) evaluated the effect of IFRS on key financial ratios of 11 quoted banks in Nigeria. Secondary data covering 6 years-2009 to 2015 were used. The study adopted the Mann Whitney U-Test approach to analyze the data comprising profitability ratios, short-term solvency ratios, Long-term solvency ratios and investment ratios. Findings indicated that IFRS has significant impact on the performance of quoted deposit money banks in Nigeria. Abba, Alabede, Okwa and Soje (2018) examined the effect of IFRS adoption on the overall asset quality of Nigerian money deposit banks. The study covered the period between 2006 to 2015 and adopted Generalized Least Square technique to analyzed secondary data on the banks listed on the Nigerian Stock Exchange Findings revealed that IFRS adoption has significantly affected asset quality of Nigerian banks.

Overseas in the Netherlands Verloop (2007) examined the effect of adoption of the International Financial Reporting Standards (IFRS) on the quality financial statement reporting among Dutch firms. The author used final sample consisting of 2,197 firm observations over the period 1985 through 2006. The firms cut across sectors of the economy. The study which employed modified Jones model of multiple regression approach showed that the adoption of IFRS has a reduces earnings management. This suggested that after the adoption of IFRS the quality of financial reporting has increased by lowering the use of discretionary accruals.

Trabelis and Trabelis (2014) examined the value relevance of accounting information for the banks listed in the Dubai Financial Market for the period 2008 - 2013. Empirical tests were based on the return and the price models of Easton and Harris (1991) and Feltham and Ohlson (1995). A sample comprising 12 banks listed on Dubai Financial Market from January 2008 to March 2014 with 214 firm-quarterly observations was used. Overall, the results showed that accounting information is associated with market valuation. The earnings are positively and significantly related to stock prices and stock returns.

Sherman and de Klerk (2015) examined the relationship between mandatory IFRS adoption and equity foreign ownership levels in top 40 listed companies in South Africa. The study which adopted ex-post facto research design covered the period 2003 to 2007 and used multiple regression model for their analysis. Their findings showed that the adoption of IFRS has no significant positive association with foreign ownership/direct investment levels during the sample period. However, it was noted that the finding of Sherman and de Klerk might have been influenced by the harmonization project embarked by South Africa earlier to align local accounting standards (SAGAAP) with the IFRS before the year of mandatory adoption in South Africa. 


\section{Research Methodology}

The research design adopted for this study is causal-comparative because the investigation revolves around what happened before and after the adoption of international financial reporting standards (IFRS) by the Nigerian banking industry. Secondary data on ten out of fifteen listed deposit money banks on the Nigerian Stock Exchange were used. The banks which were selected via judgmental sampling technique were those whose annual financial statements for the immediate year before IFRS adoption year were available and contained figures under Nigerian GAAP/SAS and IFRS-equivalent. The data which were analyzed using descriptive statistics and paired student t-test with the aid of were sourced from 2011 and 2012 annual financial reports of the selected banks except Zenith bank for which only 2011 annual financial reports were used. Zenith Bank prepared additional financial statements under IFRS for 2011 in addition to the Statutory SAS-based annual report for 2011. For the other banks, 2011 statutory SAS-based annual reports provided the SAS data while the 2012 annual reports presented the required IFRS-equivalent data of the 2011 figures. The variables of interest are grouped under Nigerian GAAP (SAS) and IFRS and they are:-average assets quality (AAQT)-proxied by loan loss provision, average loan volume (ALVM), average profit after tax (APAT) and average net interest income (ANII). The ten selected banks are: Access Bank Plc, Diamond bank Plc, Eco Bank PLc, Fidelity Bank Plc, First bank of Nigeria Plc, First City Monument Bank Plc, Guaranty Trust Bank Plc, Stanbic IBTC Bank Plc, United Bank for Africa Plc, and Zenith Bank Plc.

\subsection{Analytical Procedure and Model Specification}

The analytical procedure followed in this study involved computation of the means of the various variables of the study under the Nigerian GAAP/SAS and IFRS-equivalent and testing for significant difference for each variable. Descriptive statistics was employed and further analysis carried out on the performance of each bank on specific variables. The effect of the IFRS adoption is measured by the difference between the mean of each variable under the Nigerian GAAP/SAS and IFRS- equivalent. The model of this study is a modified version of a paired student t-test model for unequal variances adopted by Nwaubani and Ezeudu (2015) and it is given as:

$$
T=\begin{gathered}
\bar{X}-\bar{Y} \\
S_{d} / \sqrt{n}
\end{gathered}
$$

Where:

$\mathrm{T}=$ the $\mathrm{t}$-test statistic

$\mathrm{S} \sigma=$ the Standard deviation for the paired data,

$\mathrm{n}=$ the sample size/number of years

$\overline{\mathrm{X}}$ and $\bar{Y}$ are the respective means of the pair of data in $\mathrm{X}$ and $\mathrm{Y}$ groups/periods, and in the case of this study: GAAP/SAS data before IFRS adoption and IFRS equivalent data in the year of adoption. 


\section{Ml Macrothink}

Journal of Public Management Research

ISSN 2377-3294

2018, Vol. 4, No. 2

The justification for the use of 2011/SAS data and their translated IFRS-equivalent is that this approach tends to eliminate the effects of concomitant factors which also would influence performance of the deposit money banks in the post adoption era such as socio-macroeconomic variables. A model for comparing means of two categories of data usually does not have an error term to capture such other variables which are not part of the model variables but which suggestively affect outcome of the model. Therefore, the approach adopted in this study is meant to capture the effect of the IFRS adoption reasonably attributable to the fundamental differences between SAS/CBN prudential guidelines and IFRS.

Table 1. Measurement of variables of the study

\begin{tabular}{cccc}
\hline S/n & Variable & Measurement/Proxied as: & $\begin{array}{c}\text { A priori } \\
\text { Expectation }\end{array}$ \\
\hline 1 & $\begin{array}{c}\text { Assets Quality } \\
\text {-AAQT }\end{array}$ & Ratio of Loan Loss Provision to Total Loans \& & - \\
& Advances (LL/TL) & \\
2 & Loan & Total Loans \& Advances of each Banks as given & $+/-$ \\
& in the annual report & $+/-$ \\
3 & Profit After & Profit Before Tax less Total Tax Payable for the & \\
& Tax-APAT & Year or as given in the annual report & $+/-$ \\
4 & Net interest & Gross Interest Income less Total Interest & \\
\hline
\end{tabular}

Source: Authors' Measurement, 2018

\section{Data Presentation}

Table 2. Average Ratio of Loan Loss Provisions to Total Loans and Advances (ALLP/TL)-Assets Quality of the Ten Selected Banks

\begin{tabular}{ccccc}
\hline Bank & SAS & IFRS & Change in LLP/TL(IFRS-SAS) & \% Change \\
\hline Access bank & 2.95 & 3.9 & 0.95 & $32.20 \%$ \\
Diamond bank & 14.6 & 14.3 & -0.3 & $-2.05 \%$ \\
Eco bank & 0.02 & 3.72 & 3.7 & $18500 \%$ \\
FCMB & 12.7 & 6.7 & -6.0 & $-47.24 \%$ \\
Fidelity & 1.7 & 5.8 & 4.1 & $241.17 \%$ \\
FBN & 2.5 & 2.8 & 0.3 & $12.00 \%$ \\
GTB & 2.8 & 2.8 & 0.0 & $0.00 \%$ \\
\hline
\end{tabular}




\section{Macrothink}

Stanbic

UBA

Zenith bank

Ave.(aggregate)
1.6

1.3

1.5

1.9

4.472
Journal of Public Management Research

ISSN 2377-3294

2018, Vol. 4, No. 2

Source: Authors' Compilation based on 2011 Annual Reports for Zenith bank and 2011 \& 2012 Annual Reports for the others

Table 2 presents ratio of loan loss provisions to total loans and advances (LL/TL) which represent the assets quality of each of the individual banks. The average LL/TA under SAS $4.537 \%$ while it is $4.472 \%$ under IFRS. This outcome meets apriori expectation because the "incurred loss" model of IFRS/IAS39 leads lower loss provision. Relating this to assets quality implies that the part of the volume of loans the bank is carrying under IFRS may have been impaired while the bank is still waiting for the incurred loss-event to happen thus, the quality of the loan is poor.

Table 3. Average Loan Volume (ALVM) of the Selected Ten Banks (in N'Millions)

\begin{tabular}{ccccc}
\hline Bank & SAS & IFRS & Change in AVLM (ifrs-sas) & \%Change \\
\hline Access & 531,784 & 491,654 & -40130 & $-7.50 \%$ \\
Diamond & 369,939 & 416,496 & 46557 & $12.60 \%$ \\
Eco & 517,948 & 918,530 & 400582 & $77.0 \%$ \\
FCMB & 343,756 & 319,021 & -24735 & $-7.20 \%$ \\
Fidelity & 353656 & 355,892 & 2236 & $0.60 \%$ \\
FBN & $1,350,954$ & $1,366,808$ & 15839 & $1.20 \%$ \\
GTB & 707,052 & 675,518 & 27534 & $-3.90 \%$ \\
StanbicIbtc & 306,503 & 302,771 & -3732 & $-1.20 \%$ \\
UBA & 824,039 & 594,090 & -229949 & $-27.90 \%$ \\
Zenith & $1,015,305$ & $1,073,399$ & -58094 & $-5.70 \%$ \\
Average & $\mathbf{6 5 1 , 8 1 8}$ & $\mathbf{6 3 2 , 0 9 4}$ & $\mathbf{- 1 9 , 7 2 3}$ & $\mathbf{- 3 . 0 3 \%}$ \\
\hline
\end{tabular}

Source: Authors' Compilation based on 2011 Annual Reports for Zenith bank and 2011 \& 2012 Annual Reports for the others

The Table 3 above indicates that average loan volume is higher under SAS. This is linked to 
the higher provisioning and treatment of perceived impairments under SAS in Table 2 above which may lead to accrued interest being incorporated into the loan volume. Though the loan volume in lower under IFRS it does not translate to high asset quality because the delay in recognizing credit impairment.

Table 4. Average Net Interest Income (ANII) of the Selected Ten Banks (In N'Billions)

\begin{tabular}{ccccc}
\hline Bank & SAS & IFRS & Change in NII (ifrs-sas) & \% Change \\
\hline Access & 48.00 & 51.0 & 3.00 & $6.25 \%$ \\
Diamond & 53.10 & 70.60 & 17.50 & $32.92 \%$ \\
Eco bank & 28.20 & 31.30 & 3.10 & $11.00 \%$ \\
FCMB & 28.10 & 31.30 & 3.20 & $11.39 \%$ \\
Fidelity & 29.20 & 30.50 & 1.30 & $4.45 \%$ \\
FBN & 178.0 & 167.0 & -11.00 & $6.18 \%$ \\
GTB & 99.0 & 94.00 & -5.00 & $-5.05 \%$ \\
Stanbic & 29.80 & 27.60 & -2.20 & $-7.38 \%$ \\
UBA & 62.00 & 56.00 & -6.00 & $-9.68 \%$ \\
Zenith & 118.00 & 122.00 & 6.00 & $7.14 \%$ \\
Average & 67.34 & 68.13 & 0.79 & $1.17 \%$ \\
\hline
\end{tabular}

Source: Authors' Compilation based on 2011 Annual Reports for Zenith bank and 2011 \& 2012 Annual Reports for the others

Table 4 shows that the average net interest income of the banks is higher under IFRS. One of the reasons for this may be linked to "incurred loss" model of IFRS/IAS39 which does allow management discretion to bring in" perceived loss" in treatment of impairment. In other words IAS39 does not allow earnings management.

Table 5. Average Profit After Tax for the Ten Selected Banks (in N' billions)

\begin{tabular}{ccccc}
\hline Bank & SAS & IFRS & Change in PAT & \%Change \\
\hline Access & 13.7 & 5.20 & -8.50 & $-62.04 \%$ \\
Diamond & -22.20 & -13.70 & 8.50 & $-38.29 \%$ \\
Ecobank & -2.30 & 19.00 & 21.30 & $926.09 \%$ \\
\hline
\end{tabular}


FCMB

$-11.60$

11.00

0.60

$-5.17 \%$

Fidelity

6.0

4.00

$-2.00$

$-33.33 \%$

FBN

47.50

23.10

24.40

$-51.37 \%$

GTB

51.70

51.60

$-0.10$

$-0.19 \%$

StanbicIBTC

6.50

6.60

0.10

$1.54 \%$

UBA

$-16.40$

$-8.00$

8.40

$-51.22 \%$

Zenith

37.14

48.70

11.56

$31.12 \%$

Average

10.66

11.11

0.45

$4.22 \%$

Source: Authors' Compilation based on 2011 Annual Reports for Zenith bank and 2011 \& 2012 Annual Reports for the others.

Table 5 above indicates that average profit after tax is higher under IFRS. Two factors are likely to account for this. One, the delayed recognition of impairment suggests under provisioning and less charge to profit. The second reason is the restriction over earnings management/smoothering under IFRS.

\section{Results of the Paired Student T-test}

The Table below summaries the analysis and the results of the Paired Student t-test.

Table 6. Summary of the Results of the Paired Student T-test (Aggregate Means)

\section{Mean}

\section{Change}

Variables

$\begin{array}{lll}\text { Under } & \text { Under } & \text { in } \\ & & \text { value }\end{array}$

(IFRS-

$\begin{array}{cccc}\% & \text { Std } & \text { Sig. }(2 & \\ \text { tail) } & \text { Remark }\end{array}$

SAS)

Ratio of loan loss provision

$\begin{array}{cccccccc}\text { to total loans (LLP/TL) } & 4.54 \% & 4.47 \% & 0.65 & -1.43 \% & 28371 & 0.944 \\ \text { Asset Quality (AAQT) } & & & & & & \\ & 65181 & 63209 & -19724 & -3.02 \% & 155,722 . & 0.698 \\ \text { Loan Volume (ALVM) } & 8 & 4 & & & 6 & \end{array}$

Net interest income(ANII)

$67.34 \quad 68.13$

0.79

$1.17 \% \quad 7.698$

0.753 


$\begin{array}{lllllll}\text { Profit After Tax (APAT) } & 10.66 & 11.11 & 0.45 & 4.22 \% & 14.052 & 0.423\end{array}$

Source: T-test output of SPSS (20) - with “\% change" computed by the Authors.

\section{Discussion of Findings}

As Table 6 above indicates, the IFRS adoption results in under provisioning which gives rise to higher profitability but low loan volume. However, the under-provisioning implies low asset quality. Therefore, the IFRS adoption with IAS39 in force, results in poor asset quality. Again, the Table 6 shows that the IFRS results into higher net interest income for the banks because IFRS with IAS 39 in force does not allow "perceived loss" model which management exploits to manage their earnings. IFRS /IAS39 prescribes "incurred loss" model. It may be recalled that the "incurred loss" model of IFRS led to delay in recognizing impairment in credits between 2007 and 2009 which in turn led to the global financial crisis (Ernest \& Young, 2014). It may alsobe noted that when the IFRS 9 which replaces IAS 39 is fully implemented, the problem of incurred loss would be taken care off as IFRS 9 prescribes "expected credit loss" model which is similar to "perceived loss" approach. Based on the associated P-values of the t-tests, the IFRS adoption results in negative insignificant effect on assets quality, loan volume while indicating positive insignificant effect on net interest income and profit after tax. These findings partly align with the result in Elosiuba and Okoye (2018) which indicated that overall the IFRS adoption has insignificant negative effect on reported performance of deposit money banks in Nigeria. On the other hand, the finding is consistent with the outcomes documented in Yahaya, Yusufu and Dania (2015) and Akinyele (2016) thus strengthening the position that IFRS adoption has no significant positive effect on performance of deposit money banks in Nigeria. As more studies are indicating evidence that the IFRS adoption has no significant positive effect on performance of deposit money banks in Nigeria, the conflict in findings of prior studies is being settled. However, some individual banks based on descriptive statistics show significant differences on some specific measures when compared under SAS and IFRS.

\section{Conclusion and Recommendations}

The main objective of this study is to examine the effect of IFRS adoption on asset quality in the Nigerian banking sector using fundamental effect approach.

\subsection{Conclusion}

Based on the findings, it is concluded that fundamentally the IFRS adoption has no significant effect on assets quality in the Nigerian banking sector as reported at $1^{\text {st }}$ December 2012.

\subsection{Recommendations}

The Financial Reporting Council of Nigeria (FRCN) should partner with Central Bank of Nigeria to provide clarity on areas of conflict between IFRS and other existing regulations and laws in order to ensure coherence in the regulatory framework which is critical to effective implementation of the IFRS (UNCTAD, 2008). It is also recommended that FRCN 
should engage in regular review of the implementation process.

ii) The deposit money banks should on their own engage in serious training and retraining of their operations staff particularly the accounting and internal control staff on the proper application of the IFRS requirements in order to reap the gains of the adoption. The positive effect of the IFRS adoption, though insignificant suggests that the adoption is potentially beneficial to the banking sector if effectively implemented.

iii) The individual banks which experienced decline in some specific performance parameters with the exception of loan loss provision under the IFRS regime need to pay more attention to their policies and internal control systems to ensure that areas of hindrances to value addition from the adoption are identified and addressed.

\section{References}

Abata, M. A. (2015). The impact of IFRS adoption on financial reporting practice in the Nigerian banking sector. Journal of Policy and Development Studies, 9(2).

Abdul-Baki, Z., Uthman, A. B., \& Sanni, M. (2014). Financial ratios as performance measure: A comparison of IFRS and Nigerian GAAP. Accounting and Management Information Systems, 13(1), 82-97.

Ajekwe, C. C., Ibiamke, A., \& Silas, M. F. (2017). Loan loss provisions, earnings smoothing and capital management under IFRS: the case of deposit money banks in Nigeria. American Journal of Management Science and Engineering, 2(4), 58-64. https://doi.org/10.11648/j.ajmse.20170204.12

Akabom-Ita, A. (2013). Analysis of financial accounting standards and their effects on financial reporting and practices of modern business organizations in Nigeria. European Journal of Business and Management, 5(4).

Akinleye, G. T. (2016). Effect of international financial reporting standards (IFRS) adoption on the performance of money deposit banks in Nigeria. European Journal of Business, Economics and Accountancy, 4(4).

Akman, N. H. (2011). The effect of IFRS adoption on financial disclosure: Does culture still play a role? American International Journal of Contemporary Research, 1(1).

Ayuba, A. (2012). A proposed rule - Roadmap for the adoption of International Financial Reporting Standards (IFRS) in Nigeria: A research based perspective on FGN, NASB \& SEC. American Journal of Economics, Special Issue: 41-45.

Deloitte Global Services Limited-Deloitte. (2017). IAS 39- Financial Instruments: Recognition and Measurement. IAS PLUS. Retrieved from https://www.iasplus.com/en/standards/ias/ias39

Ding, Y., Hope, O. K., Jeanjean, T., \& Stolowy, H. (2007). Differences between domestic accounting standards and IAS: Measurement, determinants and implications. Journal of Accounting and Public Policy, 26, 1-38. Retrieved from https://www.elsevier.com/locate/jaccpubpol 
Eneje, B., Obidike, C., \& Chukwujekwu, P. (2016). The effect of IFRS adoption on the mechanics of loan loss provisioning for Nigerian banks. IOSR Journal of Business and Management (IOSR-JBM), 18(6), 45-52.

EIB. (2016). Banking in Sub-Saharan Africa: Recent trends and digital financial inclusion. European Investment Bank. Retrieved from www.eib.org/.../economic-report-banking-africa-recent-tre

Elosiuba, J. N., \& Okoye, E. (2018). Effect of international financial reporting standards on corporate performance of selected banks listed on Nigeria stock exchange. Annals of Spiru Haret University Economic Series, 1. Retrieved from https://papers.ssrn.com/sol3/papers.cfm?abstract_id=3162953

El-Tantawy, A. E. (2014). What is the difference between IAS and IFRS? Retrieved from https://www.bayt.com/en/specialties/q/4149/what-is-the-difference-between-ias-and-ifrs/

Eriki, E., Modebe, N. J., Okoye, L. U., \& Erin, O. (2017). International Financial Reporting Standards (IFRS) Adoption and the Performance of Key Financial Ratios: Evidence from Quoted Deposit Money Banks in Nigeria. Journal of Policy and Development Studies (An Open Access Journal), 11(3). https://doi.org/10.12816/0040641

Ernest, \& Young, E. Y. (2014). Applying IFRS: Impairment of financial instruments under IFRS 9. Retrieved from https://www.ey.com/Publication/vwLUAssets/Applying_IFRS: Impairment_of_financialinstruments_under_IFRS_9/\$FILE/Apply-FI-Dec2014.pdf

Garcia, M. (2015). What are the qualitative characteristics of accounting information? Retrieved from http://www.ehow.com/list

Herbert, W. E., Tsegba, I. N., Ohanele, A. C., \& Anyahara, I. O. (2013). Adoption of international financial reporting standards (IFRS): Insights from Nigerian academics and practitioners. Research Journal of Finance and Accounting, 4(6).

ICAEW. (2018). Knowledge guide to international accounting standards: History and development-April 2001. Retrieved from https://www.icaew.com/library/subjectgateways/accounting-standards/knowledge-guide-to-international-accounting-standards

IFRS Foundation. (2015). Analysis of the IFRS jurisdiction profiles. Retrieved from www.ifrs.org/Users-around-the-world

IFRS Foundation. (2017a). Who we are. Retrieved from https://www.ifrs.org/about-us/who-we-are/

IFRS Foundation. (2017b). Who uses IFRS standards? Retrieved from https://www.ifrs.org/use-around-the-world/use-of-ifrs-standards-by-jurisdiction/

Jamal, K. B., Shamsher, M., Taufiq, H., \& Zulkarnain, M. S. (2011). The impact of reforms on the value relevance of accounting information: Evidence from Iran. African Journal of Business Management, 5(1), 96-107.

Mande, B. (2014). Emerging nations and financial reporting complex: A case for IFRS 
adoption in Nigeria. Journal of Finance, Accounting and Management, 5(2), 1-23.

Nwaubani, A. N., \& Ezeudu, J. I. (2015). Mergers and acquisitions: An approach for addressing crisis of confidence in the Nigerian Banking Sector. Enugu State University of Technology (ESUT) Journal of Accountancy, 6(2), 139-156.

Oduware, U. (2012). IFRS adoption in Nigeria \& optimizing the gains of global investment climate. Retrieved from http://www.wecadeloitte.

Ohlson, J. A. (1995). Earnings, book values, and dividends in equity valuation. Journal of Contemporary Accounting, Research, 11(2), 661-687. Retrieved from https://doi.org/10.1111/j.1911-3846.1995.tb00461.x

Oino, I. (2015). Competiveness and determinants of bank profitability in Sub Saharan Africa. International Journal of Economics and Finance, 7(10).

Omaliko, E., Uzodimma, A., \& Okpala, N. (2017). Effect of international financial reporting standard adoption on financial performance of listed money depositing banks in Nigeria. European Journal of Business and Management, 9(17).

Owolabi, A., \& Iyoha, F. O. (2012). Adopting international financial reporting standards (IFRS) in Africa: Benefits, prospects and challenges. African Journal of Accounting, Auditing and Finance, 1(1).

PricewaterhouseCoopers-PWC. (2014). In depth Look at Current at current reporting issues. Retrieved from https://www.pwc.com/gx/en/audit-services/ifrs/publications/ifrs-9/ifrsin-depth-expected-credit-losses.pdf

PWC. (2011). Prudential guidelines: Differences between SAS 10 and the revised prudential guidelines. Retrieved from https://www.pwc.com/ng/en/pdf/nigeria_sas_10_and_new_ prudential_guidelines.pdf

Sanusi, S. L. (2010). The Nigerian banking industry: What went wrong and the way forward. Being the full text of a Convocation Lecture delivered at the Convocation Square, Bayero University, Kano. Retrieved from http://www.cenbank.org/OUT/SPEECHES/2010

Sanusi, S. L. (2010). Financial stability report (maiden edition: Jan. 2009 - Jun 2010). Retrieved from http://www.cenbank.gov.gn

Sherman T., \& de Klerk, M. (2015). International financial reporting standards and foreign ownership in South African companies. Southern African Business Review 19(1).

Shil, N. C., Das, B., \& Pramanik, A. K. (2009). Harmonization of accounting standards through internationalization. International Business Research, 2(2). Retrieved from http://www.ccenet.org

Tanko, M. (2012). The effect of ifrs adoption on the performance of firms in Nigeria. Paper presented in IFRS Conference-Challenges and Opportunities ( $1^{\text {st }}-2^{\text {nd }}$ May $)$, Organized by Qasim Univ. Saudi Arabia. Journal of Administrative and Economic Sciences, 5(2), 133-157. 
Trabelsi, N. S., \& Trabelsi, M. (2014). The value relevance of IFRS in the UAE banking industry: Evidence from Dubai financial market (2008-2013). International Journal of Academic Research in Accounting, Finance and Management Sciences, 4(4), 60-71.

Ugbede, O. I., Mohd, L., \& Ahmad, K. (2014). The effects of changes in accounting standards on earnings management of Malaysia and Nigeria Banks. European Journal of Accounting, Auditing and Finance Research, 2(8), 15-42.

Umorem, A. O., \& Enag, E. R. (2015). IFRS adoption and value relevance of financial statements of Nigerian Listed Banks. Int'l Journal of Finance and Accounting, 4(1), 1-7.

United Nations Conference on Trade and Development-UNCTAD. (2008). Practical implementation of international financial reporting standards: Lessons learned. Retrieved from https://unctad.org/en/Docs/diaeed20081_en.pdf

Verloop, M. C. (2007). Earnings quality under international financial reporting standards (A Dutch perspective). Retrieved from http://dare.uva.nl/cgi

Yahaya, \& Adenola, K. (2011). Compliance with statement of accounting standards by Nigerian quoted banks. European Journal for Financial, Economic and Administrative Services, 34.

Yahaya, O. A., Yusuf, M. J., \& Dania, I. S. (2015). International financial reporting standards' adoption and financial statement effects: Evidence from listed deposit money banks in Nigeria. Research Journal of Finance and Accounting, 6(12).

\section{Copyright Disclaimer}

Copyright for this article is retained by the author(s), with first publication rights granted to the journal.

This is an open-access article distributed under the terms and conditions of the Creative Commons Attribution license (http://creativecommons.org/licenses/by/4.0/) 